\title{
Ockham on the Concept
}

\author{
JOHN BOLER
}

University of Washington

It is a commonplace of Ockham commentary that he changed his position on what concepts are. While I see no reason to question the general lines of the familiar story, I do think there are some interesting details along the way which are not always emphasized and which raise (for me at least) the question of whether we understand just what was going on. ${ }^{1}$

The development of Ockham's thought on the topic divides, I think, into two unequal stages, the first of which can again be divided into three. ${ }^{2}$ (1) He began by favoring a sort of double aspect scheme. The act of thinking itself is a real, individual quality existing "subjectively" in the mind. But as representative, we might say, it requires an object. In his early account, Ockham posits the concept as the object of our thinking, holding that of itself it must, like a fictional entity or fictum, have merely "objective" existence and not real or "subjective" existence. ${ }^{3}$ Call this the fictum theory. (2) After

1. One cannot do better than Marilyn Adams's extensive and critical account. See the index (under "Concepts") in her William Ockham 2 vols. (Notre Dame: University of Notre Dame Press, 1987).

2. The relevant texts are listed below. Using standard abbreviations, I cite volume and page (sometimes followed by "/line(s)") of the critical edition, Gideon Gal et al., eds., Opera philosophica et theologica, 17 vols. (St. Bonaventure, NY: The Franciscan Institute, 1967-1988). It is estimated now that all these texts were written between (about) 1317 and 1324, when Ockham was called to Avignon to answer charges of heresy; however, it is difficult to be precise in dating their individual composition. For purposes of the development of Ockham's views on the concept, however, the following rough groupings seem clear enough. The earliest (131719 ) is the Reportata of his commentary on the Sentences: In I Sententiarum, d 2, q 8 (OTh II, 266-89). A middle group (1320-22?) consists of his addition to that text (OTh II, 289-92), and the Expositio in librum perihermenias Aristotelis, prologue (OPh II, 345-376). The next (1323-24?) is Summa Logicae, chaps. 12, 14, 15, and 40 (OPh I, 41-44, 47-54, 111-13). His final position is set out in Quodlibeta septem III, 8 and IV 35 (OTh IX, 232-37, 469-74), and esp. Quaestiones in libros physicorum Aristotelis (OPh VI, 396-410).

3. Adams, William Ockham, pp. 74-75. 'Object' is a word that can do many jobs, perhaps especially among medieval writers. It should be kept distinct from 'content' and even 'significatum' I shall use it as equivalent to "something cognized," where "something" can be broadly construed. 
a short time-the whole story takes place in about eight years-Ockham decided that it would be equally as probable to hold a theory that simply identifies the concept with the act of thinking. ${ }^{4}$ Call this the mental-act theory. And (3) Ockham soon enough comes to favor it over the fictum theory.

Throughout this first stage in the development of his thought, however, while Ockham's preferences change, he treats the alternate positions as plausible or "difficult to disprove." And that should give us pause; in fact, I take it as a test for any hypothesis about what is going on in this (tripartite) stage. What can Ockham be thinking of that makes him so tolerant of the alternatives? The changes cannot be anything like that from realist to nominalist, intentionalist to extensionalist or realist to antirealist; for no proponent of any of those alternatives would stand for a take-your-pick approach.

Ockham's ultimate position, in what I am calling the second stage in his development, is different in this respect; for there he rejects all alternatives but the mental-act theory. Most significantly, he offers an antirepresentationist argument as a refutation of the fictum theory. ${ }^{6}$ As we shall see, this final change carries its own interpretive problems. Marilyn Adams notes a significant shift of attention from what universal concepts are to what and how they signify; and as we shall see, there is something to the idea that Ockham is changing the topic as much as changing his mind. ${ }^{7}$

In the immediately following sections, I provide more detail on Ockham's developing position. In Section 4, I discuss the "Terminator Principle," which, I think, carries the weight in both his early and later positions. In Section 5, I develop an analogy from art to bring out what I think is peculiar to Ockham's account of ficta. Section 6 offers a guess at what is going on in the first stage of his thought. Section 7 sets out my guess about what is going on in the second or ultimate stage in Ockham's account of the concept. Finally Section 8 provides a summary and conclusions.

\section{II.}

It is helpful to review what does and does not change in the sequence of texts. As it happens, each time Ockham takes up the topic, the explicit question he asks shifts slightly. Ockham treats "passio animae," "intentio animae," and "conceptus" as synonyms; however, he tends to favor one or

4. See n. 2, above.

5. Ord. I, d 2, q 8 (OPh II, 270).

6. Sense-datum theory would be an instance of representationism, where "I see a table" would be analyzed along these lines: "I have such-and-such a sensation and (for such-and-such reasons) I conclude that I am seeing a table."

7. Adams, William Ockham, p. 107. There is something to anything Professor Adams has to say about Ockham. 
another of them depending on the context. ${ }^{8}$ The earlier passages appear under the question of the status of universals. ${ }^{9}$ There is nothing in them that would make us change our minds about Ockham's nominalism (or conceptualism). But the setting is special. For Ockham considers "universals" there as one among many things that do not or cannot exist. ${ }^{10}$ The problem, therefore, is not unlike that of accounting for our talk (or thought) about fictional things, for example, talk about Hamlet or the chimera. I shall have more to say about this, but the upshot is that Ockham claims, in the early texts, that a universal (e.g., asinus/donkey ${ }^{11}$ ), as the object of our thought, is something that has only objective existence in the mind. ${ }^{12}$

Ockham's discussion of concepts in his commentary on the Perihermenias is set in the context of Aristotle's claim that written and spoken terms are signs (notae) of "passiones animae"; and the question Ockham explicitly asks there is: "What are these passiones?" 13 The problem here is importantly different from the earlier question, for it has to do with the character or status of any concept, factual or fictional. Still, if the issue is how we should talk about the concept (or passio animae), it would not be surprising if the earlier analysis of the fictional and/or non-existent had some carryover into this treatment of concepts generally. ${ }^{14}$

The Summa Logicae is an explicit presentation of Ockham's logical (and/or semantic) schema. And he introduces concepts-_conceptus" is the favored word here-under the rubric of mental terms. ${ }^{15} \mathrm{He}$ still allows the possibility of an objective-existence theory, but he clearly favors the

8. "Synonym" may be too strong. Ockham just says that different terms have been used by various authors: Expos. perih., prologue 3 (OPh II, 349/5-8).

9. In sent. I, d 2, q 8 (OTh II, 266).

10. These include impossible things (chimera, goat-stags), fictional characters (Hamlet), things that are not contradictory but that cannot exist (the second intentional objects of logic, including propositions, syllogisms and universals), and things that could but do not exist (possible individuals before God creates them or that are never created). In sent. I, d 2, q 8 (OTh II, 273-74). Hamlet is not an impossible thing (like the goat-stag), but he cannot exist because he is by definition fictional.

11. Ockham is not concerned here about the predicate in "Brunellus is a donkey" so much as the subject in "The donkey is a mammal." Ockham agrees with Aristotle that science is about what is universal and necessary; and he has the courage of his convictions in holding that science is therefore about concepts (which signify real things): Expos. physicorum, prologue, 4 (OPh IV, 11-12).

12. A distinction between subjective and objective existence is traditional, though it may mark importantly different issues: see section 5, and esp. nn. 51 and 52.

13. Epos. perih., prologue 2-3 (OPh II, 348).

14. At this point, Ockham is thinking of the concept as an object of an act of thinking, not the act itself which has subjective existence throughout. See also n. 26.

15. For the relevant discussion of terms, see Summa Logicae, I, cc. 1-3 (OPh I, 7-14). Although the semantic project is explicit here, Ockham is working throughout with the notion of a mental language where concepts are mental terms: see the first regulative principle for concepts in section 3 , and the end of section 6 , below. 
mental-act theory, noting the advantage of its theoretical simplicity. ${ }^{16}$ In fact, Ockham has probably abandoned the fictum theory by this time; but I think it important to keep that decision separate from what lies behind the texts of what I am calling the second stage, that is, the Quodlibeta and the Questions on the Physics. The context there is how to handle second intentions, which are the subject matter of logic. And Ockham says (in effect) that he does not need the fictum theory to explain that. ${ }^{17}$ More significantly, he also introduces a new criticism of ficta for "getting in the way" of our knowledge of the world. ${ }^{18}$ I shall have more to say about that as well, but for the moment, let me turn to what does not change throughout Ockham's discussions.

Despite his changing allegiance, Ockham is consistent throughout in listing five candidate theories on the nature of the concept. ${ }^{19}$

1. One theory holds that the concept is a substance or quality external to the mind. This covers realist views on universals, not only the free-floating Ideas of the Platonists, but the "moderate" position on common natures in Scotus and others..$^{20}$ Ockham simply dismisses the proposal in these texts; though we know he has extensive criticisms of the realist positions elsewhere.

2. A second theory holds that the concept is a "species." Again, we know that Ockham has treated the issue of (sensible and intelligible) "species" elsewhere. Here, he simply rejects them as in violation of a criterion, discussed below: viz., a concept cannot exist except when the act of thinking does; species can so exist; ergo, etc. ${ }^{21}$

3. A third theory holds that the concept is identical with the act of thinking (a real quality existing subjectively in the mind). This is the mental-act theory.

4. A fourth proposal is that the concept is a real quality distinct from the act of thinking but existing subjectively in the mind. Commentators tend to ignore this candidate, and Ockham gives little attention to it. But he does offer (in one place) a consideration in its favor. As something real, such a mental quality would function rather like a statue in representing its subject; and that, he thinks, would support

16. Summa Logicae, c. 12 (OPh I, 42-43/33-39).

17. I discuss this in section 7 .

18. Quaest. physicorum, q. 1 (OPh VI, 397) ; Quodlibeta IV, q. 35 (OTh IX, 472-74). I follow the rhetoric of Ockham's antirepresentationist argument. The representationist, of course, would hardly agree that sense data, say, "get in the way," holding rather that they are the only means we have for getting knowledge of the world.

19. Expos. perih., prologue 4-10 (OPh II, 349-71). In sent. I, d 2, q 8, passim (OTh II 266-92). Quaest. physicorum, QQ. 1-6 (OPh VI, 397-410). The candidates do not always appear in the same order.

20. He manages to get Roscellin in under this rubric of the concept as external: In sent. I, d 2, q 8, (OTh II 271; and see n. 1 there.)

21. Expos. perih., prologue 5 (Oph II, 351/11-12). 
a more direct sense of "likeness" than would something having only objective existence (as in the fifth candidate) ${ }^{22}$

5. A fifth candidate is the fictum theory, holding that the concept is a quality distinct from the act of thinking but having only objective existence in the mind.

Ockham's discussions of the pros and cons of the five candidate positions appeal to pretty much the same data throughout. This is especially true in the first stage while he holds that the last three positions are all at least probable. ${ }^{23}$ Naturally enough, Ockham spends more time defending the fictum theory in his early writings and more time in his later writings defending the mental-act theory. In the end, he does argue that only the mental act theory will do. But that turns on the new argument that holds the concept-as-object would "get in the way" of our thinking about the world. ${ }^{24}$

\section{III.}

Another constant, running through Ockham's treatment in both stages, is a set of three principles that any theory about the concept must respect. ${ }^{25}$

1. Concepts must be able to supposit for and signify things naturally just as written and spoken terms do by convention.

2. If not identical with the act of thinking, concepts must exist only with it. ${ }^{26}$

22. Expos. perih., prologue 7 (Oph II, 361/46-60). Ockham concerned here with whether a theory makes the concept a real thing (a subjectively existing quality) or not; he thus contrasts the statue as itself a separate thing with something in a painting or a story. (And we do not speak of the figure "in" a statue.) Whether statues are a different (or better) sort of likeness than paintings is an interesting but different question.

23. In sent. I, d. 2, q. 8 (OTh II, 270/17-20. In other places, whether he is being altogether up front about it or not, Ockham says he will leave it to the metaphysicians, [Expos. perih., prologue 3 (OPh II, 349/8-11)], or the "studiosi," [Expos. perith., prologue 10 (OPh II, 371/34ff.)], or simply to "others" [In sent. I, d 2, q 8 (OTh II, $291 / 16-17)]$ to determine which is true.

24. Quaest. physicorum, q. 1 (OPh VI, 397) ; Quodlibeta IV, q. 35 (OTh IX, 472-74.

25. E.g., Expos. perih., prologue 4 (OPh II, 349/6-9).

26. In all these texts, Ockham is thinking of the concept as the unique content, so to speak, of an individual act of thought; and he says that this cannot be a habit: Quaest. physicorum, q. 8 (OPh VI. 414); cf. Expos. perih., prologue 5 (OPh II, 350f). But I think Ockham would describe in terms of habits those cases where we might say that someone has or lacks the concept of such-and-such. He also has the resources to handle cases where, simply as familiar with a certain language, one might use a word correctly without having the relevant concept. I suspect, moreover, that in the context at hand, Ockham is thinking of relatively simple concepts and not constructs that make up for one's lack of experience with the kind of thing referred to. 
3. There is no cognition without something cognized (cognitum).

These points are worth a closer look.

The claim that concepts are the terms of mental language and are natural signs of things is so familiar to readers of Ockham that one may miss an anomaly in its appearance in the early texts. If one focuses solely on the role of (concepts as) mental terms, there may seem to be no change throughout Ockham's writings. However, the underlying structure of that account actually changes significantly. ${ }^{27}$ In his ultimate position, Ockham holds that the relation of signs to one another and to things in the world is all that is needed to deal with the problems that led him to the fictum theory. Yet if he already had the idea of such a basic sign relation at the beginning, the interpretive puzzle is less how he finally came to take up the mental-act theory and more what kept him from adopting it in the first place. As I shall try to explain below, part of the answer to the latter question is to be found in the peculiarity of his account of ficta; and part is that he needed to develop a more sophisticated schema for signification in order to get beyond it.

The contrast of natural and conventional signs deserves a brief comment. Along with other medieval thinkers, Ockham follows Boethius in describing written and spoken language as subordinate to mental language, where the former are established by convention while the latter is "natural."28 'Asinus' and 'donkey' are conventions of Latin and English, but they are subordinate to the same concept. As the ground, as it were, for (the use of) conventional language, such natural signs have a prestigious status. Yet, since we cannot express ourselves directly in mental, there are complications about any appeal to it. ${ }^{29}$

The contribution of the naturalness of natural signs, for Ockham, can be misunderstood. It is tempting to suppose that a natural sign is in some way a better likeness or representation than a conventional sign. But the common analogy for concepts as natural signs is smoke as a natural sign of fire. Somehow, as "fire" comes to mind when I see smoke, so "donkey" arises in the mind of anyone who sees (enough) donkeys. ${ }^{30}$ Yet smoke bears no likeness to fire. ${ }^{31}$ I suppose one could say that this case of smoking is like other cases where smoking is brought about by fire, but the likeness

27. I discuss this at the end of section 6 .

28. See, for example, Summa Logicae I, c. 1.

29. Ockham seems to treat the natural signs of mental language as introspectible, but the case is surely more complex.

30. Summa Logicae II, c. 14 (OPh I, 286-88).

31. Smoke does not represent fire; so one does not locate an objectively existing fire in smoke! We discover that smoke is (natural) sign of fire when we know of the causal relation. And this is the case with the spoken term as a natural sign of the speaker: Summa Logicae I, c. 1 (OPh I, 9/3-4); it does not represent the speaker. Of course, we cannot observe the causal connection between concept or mental term and its object. Attributing naturalness to the concept-as-sign, like attributing a likeness to it, is (so to speak) a theoretical matter. 
there is between smoke and smoke. To bring fire into the picture, one needs something other than likeness. As I understand Ockham's ultimate position, what is central to natural signification of concepts (as mental terms) is not the representational (pictorial) connotation of "likeness" but rather the fact that the concept arises automatically, as it were, in our experience. ${ }^{32}$ It is an empirical fact, apparently due to the constitution of our minds, that the mental term for 'donkey' arises in the mind of anyone who sees (enough) donkeys and 'cow' arises upon seeing cows. And I think it is that fact alone which Ockham thinks makes these concepts natural signs of things and not their possessing some special internal quality, much less their revealing the essence of things (or anything close to that). ${ }^{33}$

The second principle in the list set out above is used to eliminate both realist (or externalist) accounts of the concept as well as intelligible species (candidates 1 and 2, above). Ockham's rejection of those positions is not a surprise. But again, one wants to ask what then led him to his own early idea that the act of thinking and the concept, though simultaneous, are distinct? For it is the distinctness of the concept that he ultimately objects to. This might lead one to suspect the ontological commitment of the appeal to objective existence; however, I think Ockham's ultimate criticism of the fictum theory points rather to the concept-as-object as the culprit. ${ }^{34}$ The change from the early theory, I suggest, is not just a simplification of his ontology but involves an important shift in the structure of signification. ${ }^{35}$

IV.

The third of Ockham's requirements deserves separate treatment. It appears in an early text in this form: "Something is 'understood' in any 'understanding'."36

32. Of course, Ockham frequently talks of the likeness of natural signs to their objects. Professor Adams puts more emphasis on these "likeness" passages in part, perhaps, because she sees Ockham's appeal to natural signs within a project meant to explain how concepts can represent the things they do. And she rightly argues that natural signification is not adequate to that purpose (William Ockham, chap. 4, 3); however, see her qualified conclusion on p. 132. I would like to avoid taking on the question of what Ockham's talk of likeness ultimately means for his cognitive theory. But some things seem clear enough. Ockham surely did not think that we gain knowledge of the world by looking at our concepts and judging from them some like quality in things. Further, I do not think Ockham ever wavers in his opposition to any hint of isomorphism as an account of cognition; see nn. 47 and 66 .

33. See previous note.

34. He objects to the concept as object in the fictum theory for closing off the cognitive process. See section 7 .

35. See n. 76.

36. [O]mni intellectione aliquid intelligitur. (In sent., I, d. 2, q. 8 [OTh II, 268]). I find the translation of "intellegere" (and its family) awkward. It is often translated 
And only a bit later and more fully as follows:

"Just as it is impossible for there to be vision and nothing seen, or for there to be love and nothing loved, so it is impossible for there to be cognition and nothing cognized by that cognition." 37

Frankly, I was at first tempted to suppose that this regulative principle was meant primarily to support the introduction of Ockham's awkward fictum theory and (happily) vanished along with it. ${ }^{38} \mathrm{He}$ argues there that, were there no special object to serve as the terminus of our thought of nonexistents, we would be "thinking of nothing." "In his ultimate theory, however, Ockham dispenses with these special objects and, as one might expect, with this "Terminator Principle" as well. It was something of a surprise, then, to find the principle in Ockham's latest treatment where the fictum theory is anathema: "It is a contradiction to posit an 'understanding' in the intellect unless something is "understood." 40

If we assume, as I think we should, that, in his final theory, Ockham subscribes to the same principle and not just the same formulation, it casts a different light on what changes in his position and what does not. Briefly put, it means that, although Ockham comes to reject the idea that an act of thought must have a concept as its object (i.e., that the concept is the "something cognized"), he holds throughout a strongly relational account of cognition as oriented to some object. Something needs to be said, then,

as "to understand"; and the Latin can have that special connotation. However, I think it often means simply "to think of." The cognates are too ugly to hide behind.

37. [I] mpossibile est esse visionem et nihil videri, vel dilectionem et nihil diligi, ita impossibile est esse cognitionem et nihil cognosci illa cognitione. Expos. perih., prologue 6 (OPh II, 352-53/37-39).

38. The analogy with vision has its problems. One might claim that Macbeth only seemed to see a dagger before him. However, it won't do to say that the Romans only seemed to believe in Zeus, or that eighteenth-century physicists only seemed to think that ether exists. As it happens, there are philosophers who take the contrast to mark a difference between physical and mental action. If there is nothing that undergoes being cut, no action of cutting has taken place. Yet the same does not hold for thinking, believing, wanting, and the like. One can disagree with the claim about a criterion for the mental without casting around for objects to undergo being thought about, as I think Ockham does in his early theory. In his later theory, I think Ockham can handle the problem as he does fictional entities, by regimentation.

39. Expos. perih., prologue, 6 (OPh II, 352-53). While we do not see this argument as such later on, I think the idea is retained. Ockham decides he does not need fictional objects or, most importantly, the concept-as-object. Had he abandoned the requirement for an object of thought altogether, I think he would not have had to eliminate terms for fictional objects or turned to goats and stags as the significata of 'goat-stag.'

40. [C] ontradictio est quod ponantur intellectio in intellectu quin aliquid intelligatur. (Quodlibet IV, q. 35, OTh IX, 473). 
about what Ockham means by "object" (or the something cognized). But I do not think that calls for anything extravagant.

We can begin with the analogy to vision. The verbs Ockham appeals to by way of analogy all are (or are equivalent to) transitive verbs. Of course, Ockham knows that they do not represent transeunt actions: being seen works no change in the thing seen. ${ }^{41}$ In fact, as an immanent action, seeing is something that takes place in the seer, but Ockham (rightly) treats "seeing" as strongly relational. That is, if there is no correlate-something seen-there is no action. If Sortes sees a tree, there need be no change in the tree. But unless there really is a tree, Sortes is not really seeing at all. Why should Ockham hold that thinking (cognoscere, intellegere) is like that?

Suppose the problem Ockham is dealing with could be put in this way: How should one characterize or identify a thought? ${ }^{42}$ That is, what makes a thought the thought it is? Or what makes this thought different from another? Among the many possible answers, two are of special interest for my present purposes. ${ }^{43}$ On one, thoughts differ for having, so to speak, a purely monadic character or quality quite independently of any external things they might be used to signify. On the other, the identifying property of a concept is relational: thoughts differ because of their different objects or significata. This is the claim of the Terminator Principle. ${ }^{44}$

If we take the analogy with vision strictly, while the act of seeing is "in" the agent or seer, the terminating object is an external thing of some sort (e.g., the real tree that is seen) and not something internal such as the (content of the) sensation itself. ${ }^{45}$ I do not think we have to interpret the Terminator Principle as requiring for any act of thinking that I have a particular individual (e.g., Brunellus) in mind. However, it does mean that I can successfully think of "donkey" only if that actually signifies donkeys. As I see it, this creates no more (and no less) of a metaphysical or ontological problem than would any extensionalist theory of meaning (or one that

41. Ord. I, d. 36, q. 1 (OTh IV, 550/10-15); d. 43, q. 2 (646/12-14).

42. Ockham begins with the question "What is a concept?" Once the concept is identified with the mental act, that amounts to "What is a thought?"

43. For example, when it occurs or in what mind it occurs. Consider the case of written language, where one word can be distinguished from another by physical location, but also by the letters that make them up. I assume Ockham finds no analogy there with mental terms.

44. Ockham's early account is, to say the least, ambiguous. His insistence that there must be a terminating object even for thoughts of nonexistents is clearly strongly relational; thus, when he abandons the fictum theory, it might seem that he is shifting away from that position. Alternatively, Ockham's early appeal to the objective existence of any concept-object might suggest (as I shall explain below) that he began with a monadic or internal account that is later abandoned. I will try to sort this out.

45. I think it is correct to say one sees an after-image but not an hallucination. 
takes meaning in terms of reference rather than sense). ${ }^{46}$ As such, it would seem to fit quite nicely with what I take is Ockham's basic attitude towards cognitive structure. ${ }^{47}$ And it is not the object of my criticism. What gets Ockham in trouble (and what he ultimately rejects) is not a requirement that thoughts bear an essential relation to objects but that the concept is their proper object. ${ }^{48}$ And one of the things that contributed to his adopting that unfortunate conclusion, I think, is his awkward treatment of ficta.

\section{V.}

Recall that Ockham first adopted the fictum theory in the context of our talk of non-existent things. It might help if we step back from Ockham's account, for the moment, to consider that issue in a general way. There are, as it happens, a number of ways to handle the problem. One is simply to admit fictional things into one's ontology. For example, Hamlet can be taken as a possible individual and assigned whatever ontological status one accords to possible individuals. ${ }^{49}$ Another possibility is to eliminate fictional things by regimenting their occurrence in statement-making language. In fact, the latter is Ockham's ultimate preference. ${ }^{50}$

There is an alternative approach to the problem, however, that invokes a notion of objective existence which I shall term esse objective simplex. ${ }^{51}$ As

46. The signification of (categorematic) terms, for Ockham is oriented toward their use in propositions to supposit for things.

47. Ockham's opposition to isomorphism is also relevant. As I understand his nominalism, Ockham thinks our (categorematic) concepts are useful for sorting things (donkeys from cows, say) but not as such revealing of the natures of things. That may seem to some as (or as leading to) skepticism or even some form of antirealism. But Ockham thinks the sorting is objective and applicable to real things. He can deal with scientific inquiry in terms of causal relations and other properties that he also holds are objective.

48. I think Ockham's ultimate criticism of the fictum theory shows that the concept-as-object, whatever its ontological status, was meant to bring the cognitive process to a close. It is that which leads to its "getting in the way" of our knowledge of things.

49. Ockham does come to admit some possible individuals, and I discuss this in section 6. Adams explains (and criticizes) his commitment to unactualized possibles: William Ockham, pp. 1060-61.

50. Summa Logicae, II, c. 14 (OPh I, 286-88).

51. I am not claiming an historical source for the schema for esse objective which I describe in what follows. I call it "esse objective simplex" to contrast it with a substantive metaphysical claim using similar terminology: for example, Aquinas's account of the form that is the intelligible species. There are many places where Aquinas seems to treat the status of things "in the mind" as purely representational: when I think of a stone, the stone is not in the mind but only its likeness. (De Veritate, q. 23, a. 1; cf., q. 8, a. 9 ad 4) The production of the intelligible species by the intellect, 
Ockham notes, objective existence was familiar in the traditional understanding of the contrast between ens in anima and ens extra animam, where things are "in" the mind in much the same way as they are "in" a story. ${ }^{52}$ This has the strange-sounding result that real mental qualities, such as joy and sadness or the act of thinking itself, are extra animam; however, that is only a problem of terminology and should not be allowed to confuse a clear enough idea. As it happens, however, Ockham's appeal to the device of objective existence seems to me somewhat special. His reason for proposing ficta in the early texts is that something must terminate the act of thinking about universals (inter alia) in much the same way that real things terminate, or serve as the objects of, our thinking about them. ${ }^{53}$ Objective existence is brought in after the fact, so to speak, in order to mitigate the claim such ficta might have on ontological status.

Perhaps I can bring out what I find awkward in Ockham's account by means of an analogy with art: specifically a contrast between portraits and other representative painting. ${ }^{54}$ Portraiture is, in the sense I described above, strongly relational. Take, for example, a portrait of the Queen Mum. It is not necessary that it be a good likeness or that (like a photograph) it have been done in the presence of the sitter. What makes this a portrait is simply its relation to a real sitter.

For a painting to be representational, on the other hand, no "sitter" is needed. Suppose I have made a drawing of flowers. Of course, I might have been drawing some real flowers and intended it as a sort of "portrait" with those flowers as "sitter." Yet there need be no flowers that I intended to portray. However, the drawing can still be representational and not, say, abstract. Representative art is, I think, essentially "of something." But "of

however, is significantly different. (It seems to be part of his account of what Aristotle means by the mind's "becoming the thing known": q. 2, a. 2; q. 8, a. 8) According to Aquinas, the form of heat, say, in a real object can (under the influence of the agent intellect) produce a form in the intellect that makes the knower not hot but a knower of heat. And he says that the form of heat, then, has an existence in the knower that is different from its "natural existence" (in a hot thing). Such a form, therefore, works a real change in the agent (from not-knowing to knowing): q. 3, a. 1; q. 10, a. 4 and a. 6 , ad 7; q. 24, a. 4 . Whatever one thinks of the claim, it is a substantial modification of the theory of form and not a description of representation: See Geach in Anscombe and Geach, Three Philosophers (Ithaca: Cornell University Press, 1961), pp. 94-96.

52. In sent. I, d. 2, q. 8 (OTh II. 273). When he switches to the mental act theory, instead of dropping the traditional phrase, he offers the rather strained reinterpretation of it as simply a contrast of what exists "subjectively" or really in a mental or in a physical host: Expos. perih., prologue 6 (Oph II, 358/205-6); Expos. perih., prologue 9 (368/135-39). See the similarly unconvincing gloss of "being of reason" in Summa Logicae I, c. 40 (OPh I, 113/60ff.). Also see Quaest. Physicorum, q. 3 (OPh VI, 403/99-108).

53. E.g., Expos. perih., prologue 4 (OPh II, 349/3-9).

54. It may also help to bring out my contrast of relational and monadic properties of thought. 
flowers," in that context, is a monadic and not a relational property of the painting (qua painting). ${ }^{55}$ Thus, the drawing can be "of-flowers" although there are no flowers it is "about"; it characterizes the painting in terms of an "internal" quality and not by its relation to a "sitter." 56 On this approach, one need not cast around for a ghostly "sitter" in the real world-or for that matter, in some possible or imaginary world-in order to make a painting representational.

We can, of course, use the same language to talk about the flowers in the painting that we do to talk of real flowers: there are six of them, say, or they are in a vase, and so on. But that is a convention we (should) understand well enough; when I point to the flowers, what I am pointing at is something like marks on paper or an arrangement of shapes or color patches. For the most part, people ordinarily handle such conventions for dealing with pictures and stories with no confusion. ${ }^{57}$ It would do no credit to philosophy to lag behind in this.

Objective existence in its simple form, ${ }^{58}$ then, is a descriptive device for keeping these things straight; the idea is not to multiply things but to mark different predications. ${ }^{59}$ Being-flowers, being-six-in-number, being-ina vase are real "beings" in our talk of real flowers; however, they are merely objective "beings" in our talk of things in pictures. It is the same with talk of characters in stories and plays. Shakespeare's play, for example, is like a representational painting and not a portrait. There can be no portrait of Hamlet because there is no Hamlet for it to be a portrait of. We easily slip into the idea that Hamlet has the independent status of someone who has stories told about him. This, however, is an illusion-Hamlet has no existence, subjective or objective, outside those representations of him.

Having settled Hamlet comfortably among the flowers, we can turn to the related, and perhaps more controversial, appeal to objective existence in connection with the content of any representation (fact or fiction). Consider again, the portrait of the Queen Mum. Even in the portrait-more carefully put: even when we talk about the portrait-it is possible to identify a figure that is just as unreal as Hamlet or my flowers. Although I could point to the

55. I say "qua painting" to distinguish this property from various "physical" properties such as being marks on a page, composed (or bought and sold) by someone, framed and so on.

56. The terms "of" and "about" do not make the point of themselves, and one's intuitions for them may change. I take "of-x" to be a quality (as it were) internal to the representation; and I take "about x" to be strongly relational. See also n. 74.

57. "The Purple Rose of Cairo" is Woody Allen's joke.

58. See n. 51 .

59. As a matter of notation, one can simply introduce a new quantifier for objective "being." In discussing illusions involving real things, as in Aureole's cases discussed in section 7, Adams, William Ockham, (p. 92) suggests relativizing such predications. However, it is important in esse objective simplex (at least) that no real thing has objectively existing properties. So I prefer separate quantifiers to emphasize the category difference in "existence." 
portrait and (correctly) say: "That is the Queen Mum," and even though it is a relation to the real Queen Mum that makes it a portrait, the Queen Mum is herself neither really nor objectively in the portrait. To think that someone could be in Buckingham Palace and a painting is a serious confusion, quite beyond the grammatical infelicity about the poor woman who came home in a sedan chair and a flood of tears. ${ }^{60}$

In sum, the appeal to objective existence, in the simple form I have described, does no ontological heavy lifting. ${ }^{61}$ It is simply a descriptive device intended to defuse the fallacy of figure of speech in talk about the Queen Mum and the figure in the portrait, just as it does for talk about the Queen Mum and Hamlet. Moreover, the appeal to an objectively existing thing with its objectively existing properties is relevant only when we talk or think about a representation. There is no need, however, to do that in order to use the representation. ${ }^{62}$ Trouble occurs only if thinking of something requires one to do so by thinking about a representation of that thing; for then the representation can get in the way. ${ }^{63}$

To return to Ockham, then, my guess is that the "Terminator" or third regulative principle for him amounts to the claim that all representation is like portraiture. This may sound extravagant, but it need be no more than a strongly relational theory of cognition expressed in the terminology of a

60. As it happens, there are nice questions about real things and places (Hitler, Paris) appearing in fictional accounts. This should not affect the fallacy of Figure of Speech I have described.

61. When Adams takes up Ockham's fictum theory with its appeal to objective existence, she compares it to a theory developed by Meinong, and she holds that both theories carry at least a minimal ontological commitment. (William Ockham, pp. $78 \mathrm{ff}$.). Whatever is to be said about Meinong, I do not see that every account of objective existence creates such a commitment (see n. 51, above). At first, then, I thought it was a mistake to attribute such a commitment to Ockham who insisted that no subjective existence is involved. However, her instincts about Ockham now seem to me right; although I gloss it a little differently. That is, I think Ockham's Terminator Principle does lead him to ghostly sitters; and I think his later criticism of ficta confirms this. See n. 65 , below.

62. In our usual commerce with signs, they are "transparent." Hume, although he does not use this terminology, gives the example of reading a book. One attends to the story, say, and not the letters and words. However, the sign can become opaque when something makes us attend to the sign itself: a misprint, for example. Or one may just be interested in fonts and printing techniques. Notice, of course, that transparent and opaque are not a division of signs but of the way they are taken. It is not a property or power of the sign-thing that makes the difference.

63. The student driver is at first attentive to turning the steering wheel but soon enough, without being conscious of that, concentrates on turning the corner. This is analogous to transparency, I think. That is, I see no reason to posit an "unconscious action (of turning the steering wheel)" as part of or (especially) prior to turning the corner. Perhaps the problem has to do with confusing a certain kind of explanation of an action with a phenomenological description of it. Ockham's own rejection of the fictum theory shows it was the concept as object that was the problem (for him). 
strange context. ${ }^{64}$ However, an appeal to objectively existing things within that setting can be confusing. The approach I just described in the analogy with art (and called "esse objecive simplex") can be seen as taking talk of fictional things altogether out of (what one might call) the portraiture mode in order to allow for the merely representational. But Ockham, I think, locates the appeal to objective existence within the portraiture mode. This is reflected in his later criticism of the fictum theory, where he ridicules its "little world of objectively existing entities." "55 But, as I explain below, Ockham's primary concern is with the way the concept-as-object closes off the cognitive process.

As I favor the former approach to the device of objective existence, Ockham's ghostly sitters seem to me to make for "funny ficta"; and I think he is well rid of them. ${ }^{66}$ Yet there is nothing inconsistent in his account of them; and, as I explain in the next section, he might tolerate ficta with only minor ontological discomfort if they did essential work. Moreover, Ockham's extension of the scheme to all the things that do not or cannot exist is understandable as well so long as the context has to do with how we talk about them. ${ }^{67}$ Most importantly, there is no danger of those ficta "closing off" the cognitive process before it gets to its intended objects simply because these fictional entities are just what we are talking about and not something we use to talk about anything else. In fact, there is no problem even with the concept as an object when the issue is what we are talking about when we talk about a concept.

The real trouble with his early theory comes when Ockham transfers his account of ficta to the objects of acts of thought generally. And even here objective existence is not the culprit but rather a mis-application of the Terminator Principle that treats any act of thinking as having the concept as its object. When I talk about the concept 'donkey', that concept is the object of my thought. Yet when I use the concept to talk about donkeys, the object of my thought is donkeys and not concepts. Ockham's ultimate criticism of

64. This creates a problem only for Ockham's early theory where, I claim, it results in ficta that are ghostly "sitters." In his later theory, he can simply deny that my drawing is representational, eliminating (from his regimented language) any direct reference to the flowers and replacing it by talking of the drawing or the "artist."

65. Quodlibeta III, q. 4 (OTh IX, 218-19).

66. Once he realizes that (with a more sophisticated semantics) he can do without them, Ockham has no need to revise his account of ficta. It may be also that he senses in the appeal to objective existence a tendency towards isomorphism (as in Aquinas's account of the intelligible species: see n. 51). Adams is critical of Ockham's reason for rejecting ficta (and objective existence): William Ockham, Part I, c. 3.

67. Recall that in connection with universals, the problem is the status of "donkey" in "The Donkey is a mammal," and not "Brunellus is a donkey." Difficulties with the latter come up in connection with the concept-as-object. As with all the "non-existents," the question is what are we talking about when we use the relevant terms? 
the fictum theory makes it clear that he thinks the fictum theory makes just this mistake of a confusion of objects. It is obvious, I think, that no appeal to objective existence could compensate for that.

\section{VI.}

In the tripartite first stage of Ockham's development he has not seen this problem with his early fictum theory. My guess about what lies behind the take-your-pick approach in those early phases is a rather special choice about simplicity. The issue is easiest to see in the problem of thoughts about contradictory or non-existent things. The fictum theory has a simpler semantics, where each act of thinking has its peculiar object. However, because of the Terminator Principle, it requires a more complex ontology. Conversely, the mental-act theory has a simpler ontology, with only real individuals as objects; but it needs a more complex semantics. In the middle phase of the first stage, Ockham might have said, "You take your choice and you pay the price." ${ }^{68}$ By the time of the Summa Logicae, of course, he has decided that "cost analysis" overwhelmingly favors the mental-act theory.

The problem with this reconstruction is obvious enough: while it would account for the "take your pick" character of the first stage, one cannot but be suspicious of its picture of even the early Ockham as choosing the simpler semantics. The Ockham we know and love made a career of constructing sophisticated semantics to protect his nominalist ontology. However, one should not underestimate the attractions of the early position. The oddities of ficta aside, Ockham's early theory promised a neat (simple) resolution to a whole nest of problems. It was in keeping with his nominalism and, by invoking a notion of objective existence, put a minimum strain on his ontology. ${ }^{69}$ What comes to bother Ockham about his early

68. Let me try to highlight the point with a comparison to a dispute about negative facts. I pick it up in the middle with the proponent of negative facts saying: "I don't see why you are making such a big fuss about ontological clutter; after all, negative things take up no room." (Compare: "ficta have only objective existence.") And so far as your supposed ontological simplicity goes, you have to pay for it with a more complex semantics. By having all propositions apply to the world in the same way (positive propositions to positive facts, negative ones to negative facts), I have a simpler scheme with just one relation of correspondence." At this point, I think the critic should shift his ground, arguing that his opponent does not have a good account of negation (cf., a good account of signification); and that seems to me what Ockham ultimately does. For example, the critic might point out that the negative fact theory actually eliminates negation. Of course, at this point, his opponent might reply: "So much for your folk semantics anyhow."

69. The addition is minimal, as he thinks (compare negative facts). Ontological clutter is not quantitative. What makes an ontology "lush" (to use Quine's term) is the kind of things it subscribes to. The mark of the beast for Ockham is attributing 
position is less its ontology and more its adequacy as an account of signification. To understand that, I think we have to pay attention to the semantic schema he eventually deploys and the sophisticated development that represents.

As Ockham's position develops, the problems that, grouped together, gave rise to the fictum theory come to be dealt with separately, though within a coherent scheme of modes of signification. First of all, by the time of the Summa Logicae, Ockham has opted for the strategy of regimentation to handle fictions (including impossible things). ${ }^{70}$ No object is needed for these cases if they never appear in referential position (as subjects or predicates of true propositions). Although he does not explicitly describe it as such, Ockham can counter the "thinking of nothing" charge by shifting to the signification that (in my terms) insures their being meaningful. There is no object that is a goat-stag (and so no thought referring to such an object); but the term 'goat-stag' is meaningful (and different from 'chimera') because it does signify real things: viz., goats and stags.

Once Ockham has eliminated any reference to fictional objects, the case against the concept-as-object is not far behind, though he needs a somewhat more elaborate schema to carry it off. The important case of second intention is handled under the rubric of one sign (mental act) signifying another. That is, the issue of reference to the universals of science and the second intentions of logic generally can, with a little care, be resolved in terms of individual mental acts (both as signs and significata). The Terminator Principle could now be glossed as: "There is no (meaningful) sign without a thing signified; and there is no (regimented) concept without an object." This allows Ockham to finesse talk of special objects altogether, thus sawing off the limb on which ficta were perched.

The more controversial element of this reworking has to do with possible individuals; for they cannot be satisfactorily dealt with using the strategies sketched above for dealing with fictional entities and with second intentions. Ockham seems to me to have approached the problem in two different contexts. The more straightforward case has to do with the expansion of the domain of discourse. We can interpret "All men are animals" to apply to presently existing men, to past and present men, or even to all possible men, past, present and future. ${ }^{71}$ This represents an extension of Ockham's ontology, but it requires no change in his nominalist project or (if I am right) his strongly relational account of cognition. ${ }^{72}$

to real things the properties of the representative system; it is "the worst error in philosophy" (Expos. perih., prologue, 8 (OPh II, 363).

70. Summa Logicae II, c. 14 (OPh I, 286-88).

71. Summa Logicas I, c. 72 (OPh I, 215-16). Cf., c. 33 (OPh I, 95-96).

72. Ockham is clearly concerned with issues of ontology, but I think places like this suggest that he is not obsessed about it. See n. 89 . 
The other context in which the issue arises for Ockham has to do with God's knowledge of unactualized possibles. Clearly with the Terminator Principle in mind, he insists that such things are truly understood by God even though they do not (yet) exist. ${ }^{73}$ I take this to indicate the exceptional status of this case and not that Ockham means to revoke the principle. ${ }^{74}$ In terms of my fanciful analogy, it is a sign of God's omniscience and omnipotence that He is able to produce "portraits" of things which will only subsequently come to "sit" for them.

Finally, it is important to recognize that the mental-act theory introduces some substantial modifications in the structure of mental signification itself. Of course, if one focuses just on the concept as mental term, its role will seem to be constant in Ockham's early and later theories. Yet once the concept has dropped out as the object of the act of thinking - that is, once the role of a concept-as-object has been eliminated-there remains only the act of thinking and the things which are its significata (some of which can be acts of thinking). One may not notice that the act of thinking itself is now a sign, where Ockham did not treat it as such in the fictum theory. In fact, the concept-as-act-of-thinking plays such a different role from that of the concept-as-object that "concept" might well be treated as equivocal in the two theories. ${ }^{75}$ Moreover, the sign relation itself changes. The mental-act theory is simpler not only for dispensing with the concept as object but for having a dyadic structure. If one abstracts from the oddities of the conceptas-object, the fictum theory suggests a triadic schema, where the concept is "taken" by the mental act to represent an external thing. In the mental-act theory, the relation between the concept-as-mental-act and thing signified is dyadic. ${ }^{76}$ In sum, the shift from fictum to mental-act theory is a complex and not a single issue matter.

73. "[Q]uia creatura nulllum esse tunc habuit, vere tamen tunc intelligebatur." Ord., I, d. 36, q. unica (Oth IV, 558/21-22). "[Q]uia etiam quando intelligitur creatura, nihil est, quamvis sit intellecta.” Ord., I, d. 43, q., 2 (646/23-24).

74. As Adams seems to in taking these passages as evidence that, on the mental act theory, "what makes a thought an act of thinking of $x$ is not that it is directed towards the objectively existent $x$ but rather that the really existent thought has the property of being of- $x$ " (William Ockham, pp. 1058-59). As I use the phrase "of-x," that would indicate a shift from a relational to a monadic property of thoughts/concepts. Clearly, these passages presuppose Ockham's rejection of ficta and of the concept-asobject. But I think that is not the same as a rejection of an extensionalist or strongly relational account generally.

75. This may be obscured by the constant role of the mental term itself, as I suggested above.

76. Charles Peirce is well known for his analysis of the sign relation as triadic: roughly: nothing is actually a sign until it is taken by someone (an interpretant) to represent something (an object). Ockham's own definition of "sign" (probably following Augustine) has something of that structure: a sign is something that brings something else to mind. Summa Logicae, I, c. 1 (OPh I 8-9). The mental-act theory, however, involves only the mental act and its object. 
It is so obvious that Ockham should have given up on the ghostly sitters that are his ficta that it is easy to assume that we know why he did. As with the first stage, however, I think the question of what is going on in this final change is actually more complicated even than Ockham lets on. Of course, Ockham has not abandoned the question of the nature of the concept. After all, at this stage he is unqualifiedly committed to the mental-act theory. It would be natural enough for him to focus on how concepts as mental acts function in the cognitive process; however, this does not quite explain Ockham's rejection of ficta. Why does he cast the fictum theory as pernicious rather than just profligate?

Ockham's critique of the fictum theory in the final stage turns on two claims: (1) that a fictum is not needed, and (2) that the fictum as object of thought actually gets in the way of our knowledge of external things. ${ }^{77}$ I shall take them up in order. The argument from superfluity may lead one to think Ockham's primary concern was with ontological clutter. But the Razor has as much to do with theoretical inadequacy as ontological commitment. ${ }^{78}$ What I think Ockham has in mind here by "not needed" is not so much that ficta needlessly add to one's ontology but, to adopt Newton's phrase, that he "has no need of that hypothesis." The new strategies I described at the end of the last section play an important role in allowing Ockham to adopt this approach.

It is the second claim in Ockham's attack on the fictum theory that seems to me more revealing of his motivation. It clearly makes the fictum a liability and not merely a matter of excess baggage. But it has, on the face of it, the character of an epistemological or psychological complaint more than a logical or semantical one.

Historically, it seems most likely that Ockham's change of attitude came about under the influence of Walter Chatton while they were together at the Franciscan House of Studies in London. ${ }^{79}$ Ockham came to agree with Chatton in criticizing a (broadly epistemological) position of Peter Aureole. ${ }^{80}$ Aureole takes up cases of perceptual illusion, two of which are representative. To someone in a boat floating down a river, it might come to seem that it is the trees along the bank that are moving. A second case is where, looking

77. Quaestiones in physicorum, q. 1 (OPh VI, 397) ; Quodlibeta IV, q. 35 (OTh IX, 472-74).

78. Ockham thinks that, as the result of God's free act of creation, the world already contains altogether more things than are necessary. See my "Ockham's Cleaver," Francsican Studies 45 (1985): 119-44.

79. Gideon Gal, "Gualteri de Chatton et Guillelmi de Ockham: Controversia de natura conceptus universalis,“ Franciscan Studies 27 (1967): 191-212.

80. For a detailed account, see Adams, William Ockham, pt. I, c. 3, \# 6. I follow her account of Aureole's two cases. 
at someone rapidly moving a stick in a circle, one "sees" a continuous circle and not just the point of the stick in different places. Aureole concludes, in effect, that these illusions show that "having an impression" is involved in all sense perception. ${ }^{81}$

Ockham offers a series of objections, possibly cribbed from Chatton, some having to do with superfluity but the main ones, I think, developing what we would today recognize as an anti-representationist line: that is, the "getting in the way" bit. ${ }^{82}$ Further, it would not be unreasonable to suppose that Ockham could have gone pretty directly from that realization to a rejection of the fictum theory. However-and this is my guess about what is going on in Ockham's change to his ultimate stage-I think the actual course of his thought derived from a seemingly unrelated problem about our apprehension of propositions.

Susan Brower-Toland has shown that Ockham went through something of a parallel development in his accounts of the status of concepts and of propositions. ${ }^{83}$ Ockham begins with the idea that propositions are one of the fiction-like objects of acts of thinking. And he ends up with a position (like that about concepts) in which propositions are acts of thought (perhaps composite or semantically equivalent to a composite) signifying only the individuals signified by their terms. ${ }^{84}$ Of course, there is a long medieval tradition of interest in the complexe significabile. ${ }^{85}$ Despite the label, however, it had less to do with what a proposition signifies (at least as Ockham uses that notion) and more to do with what it says: the "dictum." Again, it is the intermediate stage in Ockham's development that is revealing.

Even when Ockham has begun to have doubts about the need for ficta, he retains the idea that propositions are objects of thought. A number

81. The move from illusions to all perception is familiar as well in more recent sense-datum theories. See n. 6, above.

82. As Adams points out (William Ockham, 84-85; 549-50), Ockham was (or at least meant to be) a direct realist all along. He had originally appealed to the fictum theory to account for our ability to think of things that do not or cannot exist subjectively: universals, the materials of logical analysis (second intentions), merely possible entities and contradictory things such as chimera and goat-stags. Ockham treats all these as objects in their own right, and none of them function as intermediaries. It is the account of concepts as themselves objects (and ficta) that makes for the problem. That he might have missed this at first is not surprising: see n. 44 .

83. Susan C. Brower-Toland, "Late Medieval Theories of Propositions and Objects of Judgment: Ockham and the Fourteenth Century Debate" (Ph.D. diss., Cornell University, 2002). For the early theory: In sent. I, prologue, q. 1 (OTh I, 16). The intermediate theory: Expos. perih., prologue 6 (OPh II, 357f.). The final theory: Quodlibeta III, 8 (OTh IX, 233-34).

84. For semantic equivalence, see Quaest. physicorum (OPh VI, 410/115ff). Cf., also, Expos. perih., prologue 6 (OPh II, 355-56/110ff.).

85. See Gabriel Nuchelmans, Theories of the Proposition: Ancient and Medieval Conceptions of the Bearers of Truth and Falsity (North-Holland, 1973). 
of things might account for that. ${ }^{86}$ What seems to occasion Ockham's change of position is his own, otherwise innocuous-sounding, claim that assent and dissent from propositions presupposes apprehension of the proposition. ${ }^{87}$ If, for the moment, we gloss "apprehension" as "attending to," and if we treat our knowledge of the world around us as propositional in form, there will be some trouble in fitting in these presupposed apprehensions with the directness of our psychological or phenomenological experience. ${ }^{88}$

There are cases, of course, where we make a proposition the subject of predication: for example, "'Snow is white' is true." What Chatton (positively) and Aureole (negatively) made Ockham face was the possibility that cases he sees as direct perception would, on his account of presupposed apprehensions, require a prior attending to a proposition (and/or its terms) prior to its constituting an awareness of things. He is convinced by Chatton that this would interpose a (mental) entity-a psychological act or mental quality - between the acts of knowing and things in the world. ${ }^{89}$

As it happens, some of Ockham's earlier formulations of important notions appeal to prior apprehension of terms as well as propositions. ${ }^{90}$ It would not be a simple task to rework them, but there is no obvious reason to think he could not have carried it off. In fact, however, Ockham does not always attempt the needed reformulations; though perhaps his shortened academic career would account for that. ${ }^{91}$ In any event, it seems to me that this concern for problems in connection with the apprehension of (or attending to) propositions may well be what motivated Ockham's ultimate attack on the fictum theory as, in effect, requiring an apprehension of the concept/term that "gets in the way." I think this reinforces the idea that it is the concept-as-object-as terminator-that is crucial to his early accounts rather than their appeal to objective existence. To resolve the question definitively, it seems to me, we would need more detail about when and how the elements of Ockham's mature semantics, with its sophisticated picture of significative structure, developed.

86. The most obvious, perhaps, is the identification of the same proposition (as "content") in different acts of judgment (assent, dissent, doubt, etc.).

87. In sent., I, prologue, q. 1, a. 1 (OTh I, 16-18) and a. 6 (Oth I, 57-58); Quodlibeta IV, q. 16 and V, q. 6 (OTh IX, 376-80; 500-503). Cf., my "Ockham on Evident Cognition," Franciscan Studies 36 (1976); 85-98.

88. Quodlibeta III, q. 8 (Oth IX, 233-34).

89. Ockham could be thinking of Aquinas who says that the verbum is a terminus of our thinking (Summa Contra Gentiles bk. I, c. 53, 4; De Veritate, q. 3, a. 1), that which we know and not, as the species is, simply that by which we know: De Veritate Q. 4, a. 2 ad 3.

90. For example, Ockham's important formulation for evident cognition. Assent and dissent from propositions, Ockham says, presuppose apprehension of the proposition; and apprehension of a proposition presupposes apprehension of its terms: see n. 87 .

91. Adams, William Ockham, pp. 488-89. 


\section{VIII.}

\section{Summary and Conclusions}

Ockham began his account of the concept with a problematic about nonexisting things: universals, second intentions, possible beings, and fictional and impossible beings. He thought an object was needed to terminate our thought about such things which he described as ficta for having only objective existence. Then, in explaining the passio animae of Aristotle, he adopted the fictum theory to describe the status of concepts generally as objects of thought. It was a theory that fit with his nominalism, had a minimal impact on his ontological commitment and promised to resolve a whole nest of problems with one blow.

As I see it, the weight of this scheme was carried not by the appeal to objective existence but rather by the requirement for a terminating object of all thought. It produced what I described in an analogy with portraiture as "ghostly sitters." One might disagree with the requirement but neither it nor the special ficta create any inconsistencies. (If Ockham has a worry about objective existence, I think, it is his sensitivity to any hint of isomorphism in an account of cognition.) What causes him trouble, as is clear from Ockham's later criticism of his early position, is the identification of the concept as the object of thought generally.

Ockham gradually loses confidence in the fictum theory (favoring the mental-act theory). And part of the reason for that, I think, is that he comes to develop a more elaborate semantic scheme that finesses the need to invoke ficta by providing relatively independent solutions to the original problems. Talk about universals and second intentions becomes talk of concepts (as one mental act signifying another). At least some possible individuals are admitted into his ontology; but Ockham eliminates fictional and impossible beings, by regimenting them out of subject and predicate position. They are therefore not objects of thought but they are meaningful for signifying real things: for example, 'goat-stag' signifies goats and stags. This meets the early charge that even mention of such things would be "thinking of nothing."

By the end of this first phase of Ockham's thought about the concept (around the time of the Summa Logicae), Ockham has dispensed with the notion of the concept-as-object, identifying the concept with thought or thinking as a mental act. He then turns his attention to the semantic structure needed to support that position. The shift from fictum to mental act, however, requires a number of changes that are more complicated than Ockham lets on (or that commentators have recognized). For example, the mental act now becomes a sign and the sign process takes on a dyadic rather than triadic character. Although (rightly) dispensing with the concept-as-object, Ockham seems to me to retain a strongly relational account of cognition. At least it fits well enough with his general approach where meaning is handled 
in terms of reference (rather than sense) and where isomorphism is assiduously avoided.

In the last stage of Ockham's thinking about concepts, he goes beyond a simple preference for the mental-act theory to a full critique of the fictum theory. His concern there, however, is not so much semantics as epistemology. His early theory of the concept as the object of thought generally (and not just with fictions) would preclude the possibility of direct or immediate perception of external things by prematurely closing off our cognitive processes within the mind. My final guess is that Ockham first comes to this antirepresentationist argument in connection with the apprehension of propositions, and that the rejection of the concept-as-object falls out of that inquiry.

The whole development of Ockham's position on the concept takes place in a relatively short period of time. But our understanding of both his early and late positions would be improved by more detailed information about when and how he developed the different elements in his semantic theory. The later "epistemological" arguments, on the other hand, suggest an interesting historical counterfactual: How would Ockham have handled the reformulations that his new schema requires? 